\title{
Is One Screw Adequate to Secure the Medial Malleolus in an Unstable Ankle Fracture?
}

Jessica Mandel BA1, Omar Behery MD1, Rajkishen Narayanan BA1, Sanjit R. Konda MD,2, Kenneth A. Egol MD',2 NYU Langone Orthopedic Hospital, New York, NY and ${ }^{2}$ Jamaica Hospital Medical Center, Queens, NY

NYU Langone Health, NYU Langone Orthopedic Hospital, New York, NYa

\begin{tabular}{|c|}
\hline $\begin{array}{l}\text { BACKGROUND } \\
\text {-Ankle fractures incidence:187 per } \\
\text { 100,000 people. } \\
\text { • Indications for Medial malleolar } \\
\text { fractures Fixation: } \\
\text { • Comminution } \\
\text { •Displacement } \\
\text { - Unstable pattern } \\
\text { - Fracture pattern may preclude } \\
\text { standard fixation constructs }\end{array}$ \\
\hline $\begin{array}{l}\text { OBJECTIVE } \\
\text { The primary aim of this study was to } \\
\text { compare outcomes in patients who } \\
\text { underwent medial malleolar fixation } \\
\text { with a single vs } 2 \text { lag screws. }\end{array}$ \\
\hline $\begin{array}{l}\text { METHODS } \\
\text {-A retrospective review of } 750 \text { patients } \\
\text { treated at one academic medical } \\
\text { center }\end{array}$ \\
\hline $\begin{array}{l}\text { - Unstable rotational ankle fracture with } \\
\text { a medial fracture treated with ORIF } \\
\text { with one or two lag screws for the } \\
\text { medial malleolar fragment. (Figure } 1 \\
\text { and 2) were identified }\end{array}$ \\
\hline $\begin{array}{l}\text {-Patients were followed until healing } \\
\text { and clinically for } 1 \text { year. } \\
\text { Complications, outcomes and } \\
\text { secondary surgeries recorded }\end{array}$ \\
\hline $\begin{array}{l}\text { Data was analyzed to evaluate time to } \\
\text { union, final ankle range of motion, } \\
\text { incidence of hardware removal, and } \\
\text { rate of postoperative complications. }\end{array}$ \\
\hline
\end{tabular}

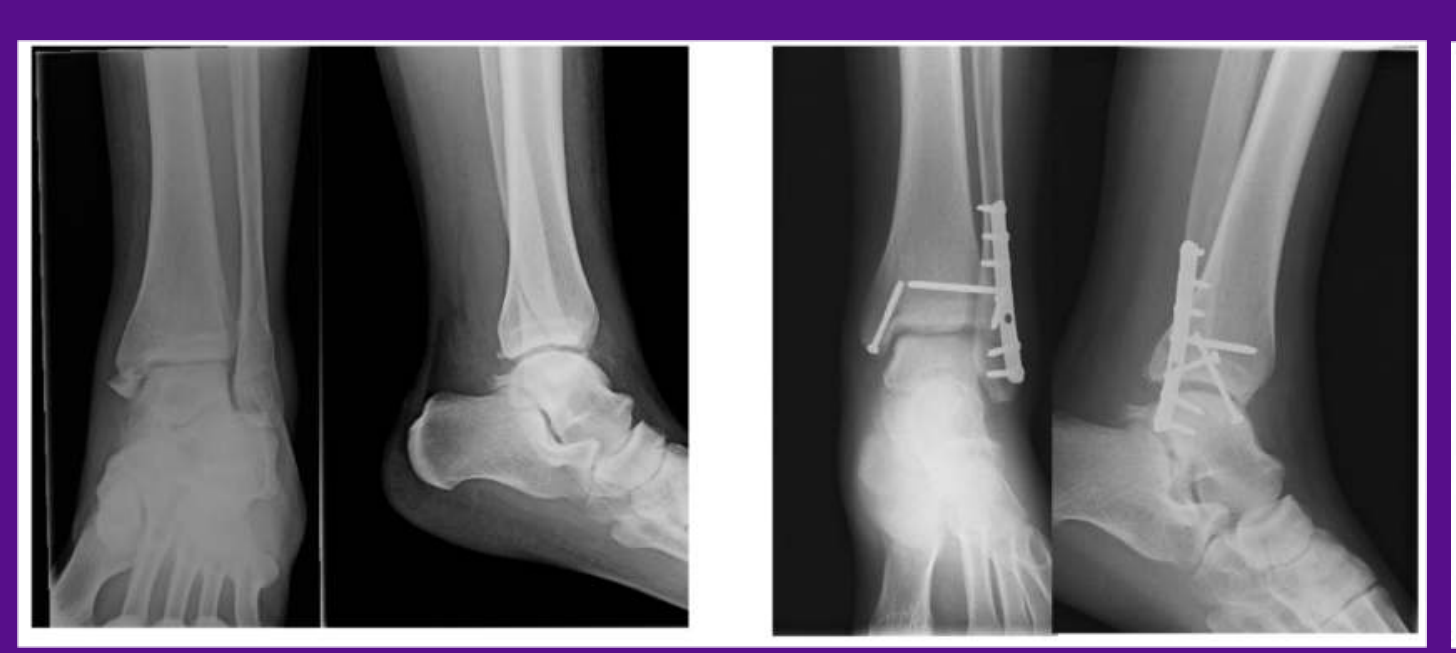

Fig 1. Pre-operative (a) Mortise and lateral radiographs demonstrating an unstable SER4 ankle fracture. Post-operative (b) AP and lateral radiographs demonstrating fracture repair with use of a single screw for fixation of the medial malleolus fragment.

\begin{tabular}{|c|c|c|c|}
\hline & $\begin{array}{c}\text { One screw } \\
\qquad N=47\end{array}$ & $\begin{array}{c}\text { Two Screws } \\
\text { N=149 }\end{array}$ & P Value \\
\hline Fragment Size AP View (mm) & $14.7 \pm 3.9$ & $16.4 \pm 3.4$ & 0.009 \\
\hline $\begin{array}{l}\text { Fragment Size Lateral View } \\
\text { (mm) }\end{array}$ & $21.4 \pm 4.7$ & $26.2 \pm 2.9$ & 0.001 \\
\hline Time to Healing (months) & $3.71 \pm 2.97$ & $3.84 \pm 2.54$ & 0.764 \\
\hline Maryland Foot Score & $83.85 \pm 18.61$ & $84.09 \pm 15.17$ & 0.924 \\
\hline Infection & $\begin{array}{c}\text { Yes }=2(3.8 \%) \\
\text { No }=50 \\
(96.2 \%)\end{array}$ & $\begin{array}{c}\text { Yes }=4(2.7 \%) \\
\text { No }=145 \\
(97.3 \%)\end{array}$ & 0.650 \\
\hline Malunion & $\begin{array}{c}\text { Yes }=1(1.9 \%) \\
\text { No }=51 \\
(98.1 \%) \\
\end{array}$ & $\begin{array}{c}\text { Yes }=1(0.7 \%) \\
\text { No }=148 \\
(99.3 \%) \\
\end{array}$ & 0.451 \\
\hline Nonunion & $\begin{array}{c}\text { Yes }=1(1.9 \%) \\
\text { No }=51 \\
(98.1 \%)\end{array}$ & $\begin{array}{c}\text { Yes }=0(0 \%) \\
\text { No }=149 \\
(100 \%)\end{array}$ & 0.259 \\
\hline Posttraumatic OA & $\begin{array}{c}\text { Yes }=5(9.6 \%) \\
\text { No }=47 \\
(90.4 \%) \\
\end{array}$ & $\begin{array}{c}\text { Yes }=14(9.4 \%) \\
\text { No }=135 \\
(90.6 \%)\end{array}$ & 1.000 \\
\hline Ankle Dorsiflexion* & $16.88 \pm 8.67$ & $15.78 \pm 8.63$ & 0.451 \\
\hline Ankle Plantarflexion* & $30.94 \pm 10.80$ & $31.93 \pm 10.58$ & 0.581 \\
\hline ROH/Revision Surgery & $\begin{array}{c}\text { Yes }=5(9.6 \%) \\
\text { No }=47 \\
(90.4 \%)\end{array}$ & $\begin{array}{c}\text { Yes }=30(20.1 \%) \\
\text { No }=119 \\
(79.9 \%)\end{array}$ & 0.093 \\
\hline
\end{tabular}

Table 1. Comparison of patient outcomes following surgically repaired medial malleolar fractures.

Fig 2. Pre-operative (a) AP and lateral radiographs demonstrating a PER4 repair of the medial malleolus.

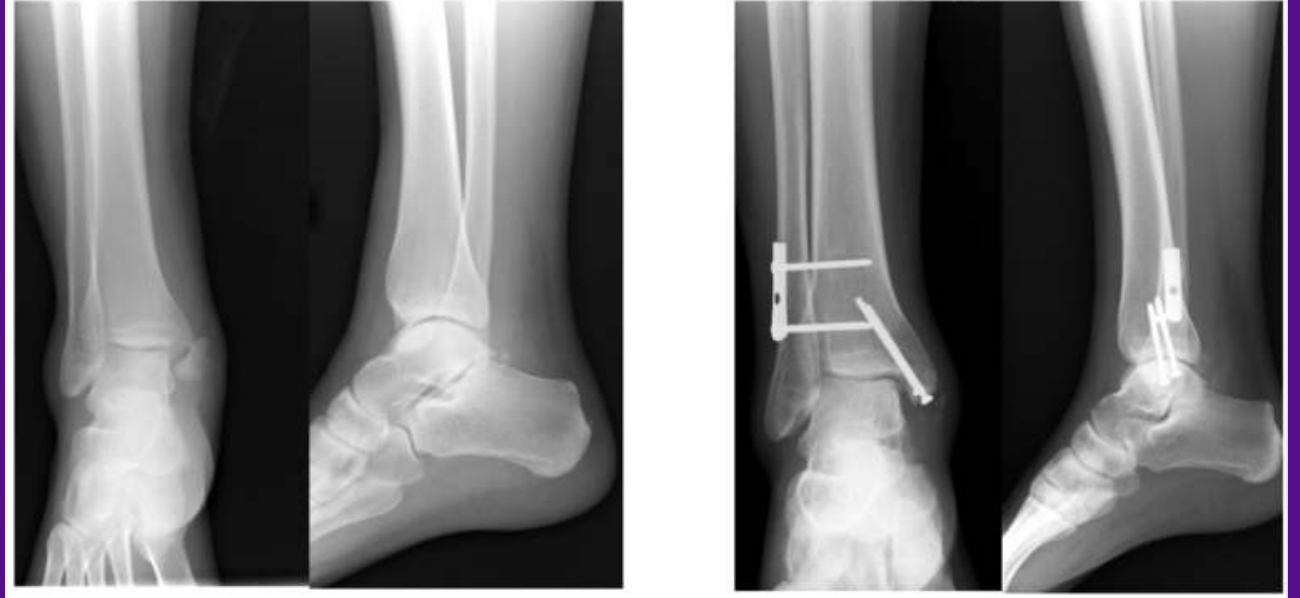
(Maisonneuve type) fracture. Post-operative (b) AP and lateral radiographs demonstrating fixation with the use of two lag screws for

Disclosure: No conflicts of interest
NYULangone Health

NYU Langone

Department of Orthopedic Surgery Division of Orthopedic Trauma

\section{RESULTS}

-196 patients met inclusion criteria.

- 47 patients $(24 \%)$ one screw.

- 149 patients $(76 \%)$ two screws.

-There were no differences among patients in age, gender, BMI, ASA, or smoking status.

-Average malleolar fragment size was smaller in those treated with one screw than those with two screws $(p=0.009$ $p=0.001$ ).

- There was no difference between groups in ankle dorsiflexion or plantarflexion at one year post-operatively $(p=0.451, p=0.581)$. -Functional scores (Maryland Foot Scores) were similar $(p=0.924)$

- There was no difference in rate of revision surgery or need for hardware removal

between groups $(p=0.093)$.

- Time to healing, and post-operative complication rate did not differ between groups.

\section{CONCLUSIONS}

-The use of a single screw for medial malleolar fixation provides stable fixation to allow ankle fracture healing, without an increase in complications.

- This information is especially important in situations when the fragment is too small to accommodate multiple fixation points. 